\title{
CONTENTS OF VOLUME 21
}

524. Measurements on the Thermal Expansiun of f'usen Silica.

Wilmer Souder and Peter Hidnert 1

j25. A Unicontrol Higir-Frequency Radio Direction hinder.

F. W. Dunmore

526. Transmission and Absorption of Sound by Some Bumding Mater RIALS_-__-_Eckhardt and V. L. Chrisler

Page

25

37

65

62\%. Short Tests for Sets of Laboratory Weigits _-_-A. T. Pienkowstiy

72S. Lxperimental Study of the Relation Between Intermittent and Nonintermittent Sector-Wheet Photographic Exposures.

Raymond Davis

529. A Review of the Literature Relating to the Normal Densities of GASES_______Marion Smith Blanchard and S. F. Pickering

530. Establishment of Radio Standards of Frequency by the Use of A Harmonic Amplifier

531. A Principle Governing tie Distribution of Curient in Sistems of Linear Conductors_-_-_._- Wenner

532. Analysis of Dental Gold Alloys_-_-_-_-_William H. Süanger

533. Relations ibetween Rotary Power and Structure in the Sugar Group. PART I- $(1$ to 10$)$ -

534. Effect of Concentrated Loads on the Length of Measuring TAPES__-_____-_Luis $\nabla$. Judson

535. A Fundamental Bagis for Measurements of Length.

H. W. Bearce

536. A Portable Radio Direction Finder for 90 to 7,700 Kilocycles.

F. W. Dunmore

537. Formula for the Inductance of a Helix Made With Wire of ANy

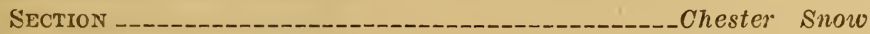

538. Spectral Energy Distribution of the Light Emitted by Plants

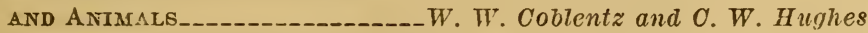

539. Radiometric Measurements on the Carbon Arc and Other Light Sources Used in Phototherapy.

W. W. Coblentz, M. J. Dorcas, and C. W. Hughes

540. Measurement of Surface Tension_____________nest Dorsey

541. A Review of the Literature Rerating to the Critical Constants of VARIOUS GaSES_-_._- Pickering

542. Electric Fiedd of a Charged Wire and a Slotted Cylindrical ConDUCTOR_-_._-_.-_Chester Snow

543. Linisage-Current Diagram for Representing Magneto Operation.

F. B. Silsbee and D. W. Randolph

544. Effect of Eddy Currents in a Core Consisting of Circular Wires.

Chester Snow

545. Determination of the Magnetic Induction in Sheet Steel.

Raymond L. Sanford and James 11 . Barry 727

546. Magnetic ReuUctivity Retationship Raymond $L$. Sanford 